\title{
The potential of Cittaslow for sustainable tourism development: Enhancing local community's empowerment
}

\author{
Dr Eerang Park \\ Lecturer in Tourism and Events Management \\ Lincoln Business School \\ University of Lincoln \\ Brayford Pool \\ Lincoln LN6 7TS \\ United Kingdom \\ P: +44 (0)1522 835537 F: +44 (0)1522835600 \\ epark@lincoln.ac.uk \\ Dr Sangkyun (Sean) Kim* \\ Senior Lecturer in Tourism \\ Department of Tourism \\ School of Humanities and Creative Arts \\ Flinders University \\ GPO Box 2100 \\ Adelaide SA 5001 \\ Australia \\ P: +61 882013039 F: +61 882013635 \\ sean.kim@flinders.edu.au
}

\begin{abstract}
The slow movement has recently offered an alternative approach to sustainable tourism development, and this study aims to investigate the potential of Cittaslow philosophy and practices for enhancing local community involvement and empowerment in the tourism sector through which sustainable tourism is better implemented. Qualitative research was conducted on the case of Goolwa in South Australia, the first non-European Cittaslow. The results reveal that not only did Cittaslow accreditation and its accompanying practices encourage local community participation in decision making processes, but also revitalised the locality of Goolwa through promoting local specialities and products, in particular food and wine. A stronger and more effective collaboration among local communities, businesses and residents after the Cittaslow accreditation was noted in the context of psychological and social aspects of local community empowerment, especially for developing and managing tourism. This paper further discusses the implications of Cittaslow through which local community empowerment and sustainability in tourism can be more achievable.
\end{abstract}

Keywords: slow city, small-scale, sustainable tourism, community involvement, psychological empowerment, social empowerment, Australia

\footnotetext{
* Corresponding author
} 


\section{Introduction}

The concept of sustainability has for some time been at the centre of tourism and destination development. The tourism literature contains substantial discussions on sustainable tourism development and sustainability in tourism, whilst seeking an alternative tourism practice amongst tourism policy-makers, practitioners and academics. The common goal of sustainable tourism development is for tourism to benefit the environment and local communities economically, socially and culturally; accordingly, the community is at the centre of sustainable tourism.

Despite the sheer volume of discussions on sustainable tourism (development), the implementation of this idea faces a number of practical difficulties (Jackson \& Morpeth, 1999; Simpson \& Roberts, 2000). They include ambiguity over the actual meaning of the concept, a shortage of implementation skills, and demand pressures. Besides these, one of the main difficulties lies in the need for collaboration with all possible stakeholders to achieve their effective participation and consistent commitment (Byrd, Bosley, \& Dronberger, 2009; Farrelly, 2011; Jamal \& Stronza, 2009). In particular, it is suggested that local residents must maintain control over tourism development by being involved in the setting of a tourism vision and developing goals and strategies for tourism development (King \& Pearlman, 2009; Okazaki, 2008). Residents also need to participate in implementing these strategies, as well as in operating tourism infrastructures, services and facilities (Sharpley, 2000; Stone \& Stone, 2011).

However, community is not homogenous, and increasing mobility and global communication negate the place-based notion of community (Cole, 2006; Richard \& Hall, 2000). A sense of community is more important to define community members (Richard \& Hall, 2000). From the view of the fluid nature of community, different groups and peoples comprise community, and conflict among people who benefit tourism in a different degree or level is manifest (Bramwell \& Sharman, 2000). A number of factors are in consideration of community participation such as different interests, a size of groups, benefits, and power; furthermore, defining participation also requires various degrees from being consultant to making a decision (Cole, 2006). Consequently, local communities are often set aside during sustainable tourism implementation, and thus social sustainability, which encompasses community involvement, is not well established (Jovicic, 2014).

More recently, a 'slow movement' is compatible with the sustainable approach. The concept of slowness, initiated by the Slow Food movement, has received growing interest from researchers and practitioners of various disciplines, including geography, sociology, and 
tourism, but research on the slow movement in the field of tourism is still in its infant stage. Slow tourism and slow travel behaviour in a broad sense of slowness are the main stream of tourism research. Researchers, initially, incorporated slowness to tourism destination branding (Conway \& Timms, 2010) and a wider slow tourism concept (Heitmann, Robinson, \& Povey, 2011). Subsequent research on slowness and tourism was approached from the environmental sustainable viewpoint by focusing on a slow mode of transport along with slow style of travel behaviour (Dickinson \& Lumsdon, 2010; Dickinson, Lumsdon, \& Robbins, 2011; Lowry \& Lee, 2011; Miretpastor, Peiró-Signes, Segarra-Oña, \& MondéjarJiménez, 2015). Widening the scope of slowness in the tourism context, socio-ecological impacts of slow tourism, in a continuum of sustainable tourism approach, were also discussed (Conway \& Timms, 2012; Dodds, 2012; Lowry \& Back, 2015).

However, Cittaslow, a type of slow movement with respect to city or town, has received a limited attention; only a few researchers have empirically tested the sustainable tourism potential of Cittaslow (e.g., Ekinci, 2014; Hatipoglu, 2015; Presenza, Abbate, \& Micera, 2015). Cittaslow, an offshoot of Slow Food, is a slow town movement. Members of Cittaslow, acting as principal agents, aim to transform their towns into community-based, visitor-friendly towns, where locality and quality of life are core values (Nilsson, Svärd, Widarsson, \& Wirell, 2011). The institutional framework devised for Cittaslow accreditation process plays in the centre of slow city movement; collaboration among community members is thus necessary. This emerging concept or movement and sustainable tourism both prioritise the town's social, cultural and environmental well-being and sustainability along with the quality of experiences (Ekinci, 2014; Heitmann, Robinson, \& Povey, 2011; Mayer \& Knox, 2006). As such, to a great extent there is a shared philosophy between the Cittaslow movement, sustainable tourism development, and community involvement and/or empowerment. However, empirical research and discussion on this troika have been limited, and little attention has been paid to the potential of Cittaslow as a function of sustainable destination development in the tourism literature. Call for further empirical studies on this has been made (Ekinci, 2014; Hatipoglu, 2015; Lowry \& Lee, 2011).

The motivation behind Cittaslow's support for sustainable tourism derives from its community-oriented philosophy and practice that encourages the participation of local communities in the development of a town with a high quality of life. Such community participation can foster a sense of place, help empower individuals of the wider community, and assist in the forging of individuals' and groups' identities. The active participation of local citizens in tourism planning and management is essential for sustainable tourism, and 
community empowerment, which is at the top of the participation ladder, ensures more viable implementation of sustainable tourism at a destination level (Cole, 2006).

Having acknowledged the above, this study aims to investigate the extent to which the Cittaslow philosophy and practice can enhance local community involvement and empowerment in relation to tourism development and management from a local perspective. This study uses the town of Goolwa, the first non-European and Australian town accredited by Cittaslow, which is located in South Australia.

\section{Literature review}

\section{Cittaslow as a vehicle for sustainable (tourism) development}

The concept of 'Cittaslow,' the so-called 'slow city movement', born in 1999, was inspired by the Slow Food movement that began in Italy in 1986, from an urgent need to counteract the increasingly fast pace of life in contemporary society, often characterised as the 'McDonaldisation of society' (Ritzer, 2011). The main philosophy behind the Slow Food movement is threefold: (1) the preservation of gastronomic traditions and biological diversity, (2) the promotion of network building among small-scale businesses and between producers and consumers, and (3) the enhancement of the knowledge of food, nutrition, and the environment (Mayer \& Knox, 2006; Nilsson et al., 2011; Parkins \& Craig, 2006). Although the Slow Food movement and Cittaslow share the same principles, the latter extends its philosophy into towns and cities. By essentially complying with the Slow Food guidelines, a Cittaslow improves the local area and conserves the environment; as such, it aims to provide a high quality of life in a place that is more liveable for both visitors and residents.

To be accredited as a Cittaslow, a town or city with fewer than 50,000 residents must fulfil a number of rigours criteria across the seven principal policy areas (e.g. environmental; infrastructure and transport; town and landscape; quality of everyday life; economy, industry and tourism; culture, heritage and social inclusion; and partnership). Consequently, from a tourism destination perspective Cittaslow is geographically confined to small-scale towns or cities. Cittaslow members maintain their accreditation by periodically verifying their compliance with the rules every five years. As of April 2015, 195 cities in 30 countries around the world have chosen to improve their residents' quality of life as well as to share their ideas, experiences and knowledge through these networks (Cittaslow, 2015).

Previous studies (e.g., Mayer \& Knox, 2006; Nilsson et al., 2011) have identified the value of Cittaslow along with its eight principles: (1) to preserve and promote local distinctiveness or place identity; (2) to provide for the well-being of residents, especially 
through encouraging the eating and enjoying of healthy food; (3) to foster traditional cuisine and gastronomy; (4) to support and encourage local culture and heritage; (5) to support and encourage local products, events, farmers' markets and small-scale businesses; (6) to work towards a more sustainable environment; (7) to support networking between the community, businesses and the local council; and (8) to empower the local community to participate in the decision-making process. The Cittaslow movement not only encourages the social, environmental and economic sustainability of the community (Presenza et al., 2015), but also supports local governance as their self-assessment of the criteria, followed by their involvement in controlling quality of life, is inevitably active (Pink, 2007).

The features of locality and local communities prevail in Cittaslow across its different applications in various contexts of sustainable development. In the field of sustainable urban planning and development, previous studies have addressed how globalisation has influenced urban design and landscape in relation to the homogenisation of cities and the authenticity of places (Hoeschele, 2010; Knox, 2005; Mayer \& Knox, 2006, 2009; Pink, 2008; Radstrom, 2014). They suggest that Cittaslow helps reduce the harmful effects of globalisation and sustain place identity by preserving its sense of place or local distinctiveness, which is also an essential part of sustainable tourism destination. Pink (2008) also highlights how Cittaslow not only offers locally specific knowledge and skills (e.g., cooking, handcrafts and business skills) but also encourages economic sustainability for small local businesses. Furthermore, Mayor and Knox (2006) consider Cittaslow to be an alternative sustainable urban development agenda that focuses on the socio-economic well-being of the local community (e.g., skills building, job security), environmental protection (e.g., natural resources and biodiversity maintenance, the promotion of renewable energy sources and recycling) and cultural strengths (e.g., paying attention to historic towns, cultures, sense of place and food events).

Although the primary goal of the Cittaslow network is to achieve quality life of residents, a review of the literature supports the view that the main feature of Cittaslow is directly related to sustainable tourism development on a small scale (Ekinci, 2014; Hatipoglu, 2015; Nilsson et al., 2011). At the destination level, Nilsson et al. (2011) examined how the Cittaslow concept influenced heritage destination development and the marketing exclusiveness of the destination, and discussed the potential of Cittaslow for tourism development by highlighting the significant role of local resources and networks in tourism development (e.g., promotion of local farming and small-scale businesses, preservation of heritage, and the development of a network with other Cittaslow towns). Ekinci (2014) 
asserted that it is easier to achieve sustainable tourism development at the global level by increasing the number of Cittaslow members, given that the requirements of Cittaslow encompass indicators of sustainable tourism development. Mayer and Knox (2009) also argue that the action-oriented criteria of Cittaslow are a powerful indicator of authentic and sustainable place-making. Hatipoglu (2015) viewed Cittaslow as a model for grassroots urban development, because Cittaslow pursues high quality of local life and a strong sense of community by supporting local businesses, organisations, and alternative local development programmes. In the case of Vize, one of the nine Cittaslow towns in Turkey, it has been shown that communities played a key role in changing the environment and tourism by actively participating in a slow food festival and promoting the uniqueness of the destination (Hatipoglu, 2015). It was also found that the Cittaslow philosophy and framework guided both policy-makers and communities towards sustainable tourism development as it facilitated the coordination of activities and collaboration among stakeholders for the agreedupon destination identity (Hatipoglu, 2015; Presenza et al., 2015).

The above concurs with what others suggested in their studies on the case of Seferihisar, the first Cittaslow member and several other towns in Turkey (Ekinci, 2014), the first two Cittaslow designated towns in the U.S (Lowry \& Lee, 2011), and Aylsham, Britain's second Cittaslow town (Pink, 2007). Therefore, the close relationship between Cittaslow and sustainable tourism development is arguably worthy of investigation, yet research on Cittaslow in this regard is relatively limited. More importantly, little effort has been made to explicitly research local communities' empowerment and involvement in sustainable tourism development through Cittaslow. As previous studies have suggested the sustainability of Cittaslow, especially with regard to the local community's active engagement with the implementation of Cittaslow, it is indeed sought after as a vehicle for sustainable tourism development with particular implications for community empowerment achieved by the community's proactive involvement in tourism planning and development.

\section{Local community involvement and empowerment}

Local communities, either directly or indirectly, encounter both the positive and negative impacts of tourism activities, and thus their participation is necessary to ensure that tourismgenerated benefits meet their needs (Cole, 2006; Tosun \& Timothy, 2003). Also, local communities understand the nature and characteristics of their tourism products more intimately than outsiders, as tourism products and activities are often associated with local rituals, traditions, and cultural values and meanings. It is, therefore, local communities who 
are more likely to know what will be appropriate for the local situation in the process of tourism planning and development (Tosun, 2006). Local communities are thus recognised as a pivotal resource and an essential ingredient in every aspect of tourism activities, and the importance of their inclusion and participation from the beginning of tourism planning has been widely acknowledged within the context of sustainable tourism and community-based tourism (e.g., Bramwell, 2010; Lapeyre, 2010; Saarinen, 2010; Stone \& Stone, 2011). As discussed earlier, this essence of community involvement in sustainable tourism development is compatible with its counterpart in Cittaslow implementation, that is, locals' knowledge and skills enhance local economic and social well-being; therefore, enhanced communication between residents, local businesses and (local) governments provide better opportunities to develop the community in a more sustainable manner (Pink, 2008).

Meanwhile, local community involvement is encouraged through the redistribution of power (Friedmann, 1992). In pursue of alternative development which is centred on people or community and environment, Friedmann (1992) asserts that changes begin at the local scale by attempting balance of power relationship and through new forms of political participation in planning, communal actions and economic organisation. According to Friedmann's (1992) alternative development notion, a process of social and political empowerment is essential for a long-term development objectives and strengthening powers of civil society in management of own affairs. It is therefore recognised that the traditional top-down approach and centralised decision-making process of tourism development excludes the voices of local people (Scherl \& Edwards, 2007), and thus community involvement in tourism development is far less likely to be achieved in any practical way (Briassoulis, 2002; Yüksel, Bramwell, \& Yüksel, 2005). Previous studies assert that sustainable tourism cannot be achieved without community empowerment (Cole, 2006; Strzelecka \& Wicks, 2015).

The concept of empowerment is therefore considered a key theoretical term that describes the capacity of individuals or groups to determine their own affairs in the context of community development (Adams, 1990; Rappaport, 1987). According to Cole (2006, p. 631), empowerment represents "the top end of the participation ladder where members of a community are active agents of change and they have the ability to find solutions to their problems, make decisions, implement actions, and evaluate their solutions." Community empowerment can thus be seen as a process by which local communities acquire the right and power to gather resources to meet their needs, as well as make decisions and control changes in order to achieve autonomy, self-reliance, social justice, and to maximise the quality of their lives (Friedmann, 1992; Scheyvens, 1999, 2002). 
As such, the notion of empowerment implies an alternative development, and a growing body of literature is evident on community empowerment and its role in enhancing local community involvement in tourism planning and development (Goodwin, 2007; Strzelecka \& Wicks, 2015; Telfer, 2003; Weng \& Peng, 2014). It has been suggested that genuine community consultation and a more inclusive approach to tourism planning through empowerment underpins active community involvement, because it is those who exercise power who are more visible in tourism planning and development (King \& Pearlman, 2009).

\section{The dimensions of local community empowerment}

Multidimensional theoretical conceptualisation on empowerment in tourism studies has been more frequently adopted since an introduction of Scheyvens' (1999) four dimensional empowerment framework to establish the centrality of community participation in the advocacy of tourism integrated conservation and development projects (ICDPs). This framework was grounded on two important studies conducted by Freidmann (1992) who viewed poverty as a consequence of social, political and psychological powerlessness and Akama (1996) who touched social and economic empowerment in the context of naturebased tourism.

A range of operationalising the concept of empowerment has been attempted in numerous empirical studies (e.g. Boley \& McGehee, 2014; Boley, Maruyama, \& Woosnam, 2015; Mendoza Ramos \& Prideaux, 2014). Some adopted three dimensions of Scheyvens' (1999) original framework, whereas others used the full analytical framework of community empowerment. Considering the nature and purpose of tourism development, economic dimension is worthwhile to investigate independently. In this respect, Scheyvens' fourdimensional framework is deemed to be suitable for applying to various levels of tourism destination from a holistic approach. Therefore, Scheyvens' (1999) four dimensions of empowerment - economic, psychological, social, and political empowerment - underpin the current study and serve as its analytical framework.

According to Scheyvens $(1999 ; 2002)$, economic empowerment refers to the fair distribution of economic gains generated by tourism activities among local communities, especially among disadvantaged groups, including women and people of low socio-economic status, rather than local elites and external investors. This economic empowerment is therefore expected to provide long-term financial benefits to local communities and encourage the creation of small businesses. 
Psychological empowerment refers to the extent to which members of a local community have pride and self-esteem in their cultural traditions and natural values, and have a positive belief in their future. This psychological empowerment will become visible when there is outside recognition of and respect for the value of the cultural traditions and natural heritage of the local community (Scheyvens, 1999; Weng \& Peng, 2014). Such recognition will not only increase feelings of community-pride, but may also increase local enthusiasm for sharing their traditional knowledge and experiences with visitors (Timothy, 2007).

Social empowerment refers to the circumstances in which a sense of cohesion and the integrity of a local community are recognised and strengthened. Timothy (2007) suggests that social empowerment can lead to a growth in confidence in a collective social identity and in stewardship over resources, thus increasing the preservation of cultural traditions and the conservation of a community's natural resources.

Political empowerment refers to the extent to which all community members have a voice in the decision-making process over the conception and implementation of development. Friedmann (1992) emphasises that a priori social empowerment should be translated into political empowerment, so that the needs of community members and localities are effectively acknowledged. If community members are to be politically empowered to have control over tourism activities, their voices and concerns should guide the development of any tourism initiative from the feasibility stage through its implementation (Scheyvens, 2002).

\section{Research Method}

\section{The research context}

The geographical focus of the research is Goolwa, the first Australian and non-European Cittaslow town that was officially accredited in 2007. Goolwa is a town in the Alexandrina Council region, located at the mouth of the Murray River on Lake Alexandrina, and is approximately $83 \mathrm{~km}$ south of Adelaide, South Australia. Since the accreditation of Cittaslow, the town has developed and promoted various new tourism activities and events with active local community involvement.

It is noted that Goolwa has paid a special attention to tourism while achieving a broad agenda of Cittaslow. Five special interest groups within Cittaslow Goolwa were established to develop relevant local community projects and activities, of which Heritage and Tourism Group has been dedicated to support networking of tour operators and tourism projects in the specific postcode region around Goolwa. The Heritage and Tourism Group, the main 
community body that promotes Goolwa as a tourism destination works closely with Food and Wine Group and Events and Fundraising Group in developing tourism projects, events and activities (Cittaslow Goolwa, 2014). Around Goolwa, which has links to the annual South Australian History Week in May each year, is one of the major new events developed and managed by the community. This is a series of tourism events where visitors and local residents can explore the historical and heritage buildings in Goolwa and discover other key secrets of the town. Some of the events include a Wrecks and River boat cycling tour, Mundoo Island tours, a Ghost Tour of Goolwa, a Beatles night, a Graze Around Goolwa, which is a gastronomic tour, projects for primary school students and the History Room, Picnic in the Park, and the Living Legends of Goolwa History Dinner (Cittaslow Goolwa, 2014).

In the case of Goolwa, food and wine along with history and nature are identified in developing and promoting local identity, and tourism was an important conveyor of those characters through events and visitor activities. More importantly, such tourism projects were developed by community groups through the implementation of Cittaslow. Research on Cittaslow and its implications to date largely deals with the European context. In addition, tourism study pays little attention to Cittaslow tourism implication, which needs further empirical studies (Ekinci, 2014). Noting the visible tourism efforts and outcomes of the community group, this study selects Goolwa as a first non-European Cittaslow, to explore community involvement and empowerment through tourism development in association with Cittaslow implementation.

\section{Research design, data collection and analysis}

This study explores the influence of the Cittaslow accreditation on the local community's involvement in tourism development and the extent of their empowerment throughout the Cittaslow implementation process. The primary data for the study was collected using indepth interviews with various local community members ranging from a local government officer (Respondent 1: R1), to a member of Cittaslow Goolwa (R2), to local business communities (R3-7: a restaurant and café, a souvenir shop, accommodation, and a food supply/distribution firm). The inclusion of various community members is supported by previous studies on local community perspectives on the impacts of tourism to reflect the different interest groups and individuals with the community (Moyle, Croy, \& Weiler, 2010). The data collection process occurred in October 2012, and the interviewees were selected based on an initial judgement and a purposive sampling method, followed by snowball 
sampling whereby each interviewee was asked to establish other contacts to take part in the research (Bryman, 2004).

The two key informants were one of the authors' existing local contacts and were accessed directly for an in-depth interview. One had been working for 15 years as a government officer for the Alexandrina Council, where Goolwa is located, and the other was a volunteer at the Visitor Information Centre in Goolwa, having already worked elsewhere for 13 years, and was also a member of the local Cittaslow group. Through the data collection process, a total of seven local community members agreed to participate in interviews. The precondition for the recruitment of interviewees was that they should have lived in Goolwa long enough (at least 5 years at the time of the interview) to be able to comment on the influence of Cittaslow on local community involvement and empowerment. Face-to-face semi-structured interviews were conducted in Goolwa. In order to avoid losing any of the verbal replies of the respondents, the interviews were audio-recorded with the verbal permission of each interviewee. Each interview lasted approximately 60 minutes. To ensure internal validity, interview transcripts were sent to interviewees via email, for them to confirm that their voices and opinions were correctly reflected.

The analysis of collected interview data was on the basis of qualitative content analysis which not only emphasises emerging categories or themes out of data but also recognises the significance for understanding the meanings in the context in which an item being analysed appeared (Bryman, 2004). The four steps suggested by Ritchie, Spencer, \& O’Connor (2003) were applied: (1) identifying initial themes and constructing an index; (2) labelling the data; (3) sorting the data; and (4) summarising or synthesising the data. The first stage involves generating a list of themes from the data and constructing a hierarchical index of main- and sub-themes. The identified themes are then interpreted in reference to the signs of empowerment and disempowerment suggested by Scheyvens' (1999) four dimensional empowerments including social, political, psychological and economical. The second stage is to apply the index to the collected raw data, which refers to labelling or indexing. The labelling determines which themes were being mentioned or referred to within a particular section of the data. Table 1 demonstrates the identified themes and indexing of the interviews data. 
Table 1 Summary of identifying themes and indexing

\begin{tabular}{|c|c|c|c|}
\hline & Verbatim/items & Themes & $\begin{array}{l}\text { Disempowerment/ } \\
\text { Empowerment }\end{array}$ \\
\hline \multirow[t]{4}{*}{$\begin{array}{l}\text { Pre- } \\
\text { Cittaslow }\end{array}$} & $\begin{array}{l}\text { 1.1. Do their own business } \\
\text { 1.2. No real engagement ( } 2 \text { ) } \\
\text { 1.3. Little engagement between them } \\
\text { 1.4 No cohesion or connection between council, } \\
\text { business and resident }\end{array}$ & $\begin{array}{l}\text { 1. Indifference and } \\
\text { disharmony }\end{array}$ & $\begin{array}{l}\text { Social } \\
\text { Disempowerment }\end{array}$ \\
\hline & $\begin{array}{l}\text { 2.1. Not invited } \\
\text { 2.2. Seldom/hardly encouraged (2) } \\
\text { 2.3. No input from the community } \\
\text { 2.4. All making it somewhere else }\end{array}$ & $\begin{array}{l}\text { 2. Lack of } \\
\text { encouragement }\end{array}$ & $\begin{array}{l}\text { Political } \\
\text { Disempowerment }\end{array}$ \\
\hline & 3.1. No idea about the committee members & $\begin{array}{l}\text { 3. No recognition } \\
\text { of tourism } \\
\text { committee }\end{array}$ & \\
\hline & $\begin{array}{l}\text { 4.1. Taking their own decision somewhere else } \\
\text { 4.2. No real power } \\
\text { 4.3. Not given any power } \\
\text { 4.4. Takes a lot of power away from the local } \\
\text { community }\end{array}$ & $\begin{array}{l}\text { 4. One way } \\
\text { decision making } \\
\text { process }\end{array}$ & \\
\hline \multirow[t]{6}{*}{$\begin{array}{l}\text { Post- } \\
\text { Cittaslow }\end{array}$} & $\begin{array}{l}\text { 5.1. Meet regularly with meetings } \\
\text { 5.2. Listening to the community } \\
\text { 5.3. Started to build a strong relationship with council } \\
\text { 5.4. Really/indeed encouraging (2) } \\
\text { 5.5. We had to assess it } \\
\text { 5.6. They know what we really wants }\end{array}$ & $\begin{array}{l}\text { 5. Respectful } \\
\text { collaboration } \\
\text { between the } \\
\text { stakeholders }\end{array}$ & $\begin{array}{l}\text { Political } \\
\text { Empowerment }\end{array}$ \\
\hline & $\begin{array}{l}\text { 6.1. A lot of cohesion and connection } \\
\text { 6.2. A huge community involvement group } \\
\text { 6.3. Grow together* } \\
\text { 6.4. Brought all their experiences } \\
\text { 6.5. So many volunteers taking ownership of the town } \\
\text { 6.6. Members working together ( } 3 \text { ) } \\
\text { 6.7. [Like to] get involved ( } 7 \text { ) } \\
\text { 6.8. Now contributing } \\
\text { 6.9. Put something back into the community } \\
\text { 6.10 Draw together for support } \\
\text { 6.11 Not to make money / Not all money }\end{array}$ & $\begin{array}{l}\text { 6. Social harmony } \\
\text { and community } \\
\text { cohesion }\end{array}$ & $\begin{array}{l}\text { Social } \\
\text { Empowerment }\end{array}$ \\
\hline & $\begin{array}{l}\text { 7.1. Improving public services } \\
\text { 7.2. Education program } \\
\text { 7.3. Encouraging local produces }\end{array}$ & $\begin{array}{l}\text { 7. Community } \\
\text { development }\end{array}$ & \\
\hline & $\begin{array}{l}\text { 8.1. Promoting balance } \\
\text { 8.2. Balance lifestyle (2) } \\
\text { 8.3. Buy locally } \\
\text { 8.4. Quality of life (4) } \\
\text { 8.5. Mindset and philology } \\
\text { 8.6. Promoting the values (of Goolwa) }\end{array}$ & 8. Quality of life & \\
\hline & $\begin{array}{l}\text { 9.1. Being proud of their town (2) } \\
\text { 9.2. Positive idea involved } \\
\text { 9.3. Proud to be part of Goolwa } \\
\text { 9.4. A good talking point } \\
\text { 9.5. Taking pride and ownership } \\
\text { 9.6. Very enhanced in our pride } \\
\text { 9.7. Self-esteem (2) } \\
\text { 9.8. Great achievement }\end{array}$ & $\begin{array}{l}\text { 9. Self-esteem and } \\
\text { community } \\
\text { pride }\end{array}$ & $\begin{array}{l}\text { Psychological } \\
\text { Empowerment }\end{array}$ \\
\hline & $\begin{array}{l}\text { 10.1. Buy locally } \\
\text { 10.2. Financial benefit (for a long-term) } \\
\text { 10.3. Benefit the region }\end{array}$ & $\begin{array}{l}\text { 10. Long-term } \\
\text { economic } \\
\text { benefit }\end{array}$ & $\begin{array}{l}\text { Economic } \\
\text { Empowerment }\end{array}$ \\
\hline
\end{tabular}

Note: Number in parenthesis shows number of interviewees commenting exactly same word(s) in interviews; * denotes an item connoting both social and economic empowerment. 
The third step is to sort or order the indexed data in material with similar content or properties together. The final stage of data analysis involves synthesising the data. By summarising the labelled and sorted data, this step requires a comprehensive inspection on each passage of the data in terms of its meaning and relevance to the themes. Textual interpretation is then applied to clarify the responses under a coherent and logical structure, with particular attention to shared patterns of expression and the overall interpretative frame on which such talk relied (Bryman, 2004; Ritchie et al., 2003). In addition, a combination of a content analysis technique and textual interpretation was used to clarify the responses. No attempt at any modification of syntax or grammar was made to represent the best voice of the interviewees, and thus all quoted comments are presented in the exact words of the interviewee.

\section{Findings}

\section{Pre-Cittaslow: lack of community involvement and empowerment}

Previous studies have pointed out the difficult practice of community participation despite its significance for the success of sustainable tourism (Mendoza Ramos \& Prideaux, 2014; Nault \& Stapleton, 2011; Simpson, 2008). The interviews in this study confirm that there was insufficient community involvement in tourism development in Goolwa prior to the accreditation of Cittaslow. The reasons identified from the interviews include: (1) indifference and disharmony; (2) lack of encouragement, (3) no recognition of tourism committee members, and (4) one-way decision-making process.

The local community perceived that their involvement in tourism planning and development was scarce. Based on the conventional top-down approach, every initiative of decision-making, implementing and evaluating tourism development programmes was driven and managed by central and local governments, such as the Fleurieu Peninsular Tourism Authority, Alexandrina Council, and the South Australia Tourism Commission (hereafter SATC). Such relationships with the government (e.g., the council and the tourism organisation(s)) hindered the local community's social empowerment, and thus resulted in indifference and disharmony among locals, as R1 remarked that "The business people, whether they are the owner of café, local restaurant, souvenir shop, or local garage, do their town business only. There is little engagement between them in the town."

The absence of social empowerment, which provides a foundation for further political empowerment (Friedmann, 1992) appears to have discouraged local people's involvement in decision-making processes. The exclusion of community's voice was demonstrated by R2's 
comment that "I had no idea about who the committee members were and who elected them. The tourism operators and business people were seldom encouraged to get involved in any decision making process. I mean they were literally not invited." It is explained that, prior to the Cittaslow accreditation, the local community was a disempowered and unequally important stakeholder in tourism development; as such, limited community involvement in the tourism decision-making process was inevitable.

The politically disempowered community rarely felt that its members were encouraged, and consequently included in any decision-making process of tourism development. Rather, the community claimed that local and central governments did not attempt to listen to the community's voice. The following comment exemplifies this:

Because the community was not given any power from the government, I mean the council, the SATC, something like that...I mean, if you don't know what is happening, you can’t be outgoing in your sharing and also don’t feel like "well I can help make a better decision", because they are all making their own decisions somewhere else without you (R2).

There was not any cohesion or connection between the council, the business people, and the resident, and there was no real engagement or power from the vast majority of the community (R7).

Sebele (2010) suggested that the lack of community involvement and participation in the decision-making process was always challenging in the context of community-based tourism, and the above findings confirm this by highlighting how local community as a stakeholder in Goolwa were not treated as equal partners in tourism planning and development. The disempowered community members were given little opportunities to take part in discussions and further decision-making processes on local (tourism) issues, nor were they encouraged to contribute so that better decisions reflecting their voices could be made. This is similar to what Gang (2010) and Nyaupane, Morais, and Dowler (2006) summarise from their studies in the Chinese and Nepalese contexts, whereby the power of the government enabled them to completely control all tourism activities, leaving local communities without any active participation in tourism planning and development. 


\section{Post-Cittaslow: enhanced local community involvement and social, psychological and political empowerment}

Although the participants collectively mentioned that it took time for Goolwa and its community members to understand the concept and benefits of Cittaslow, all the relevant stakeholders (e.g., the council, the Cittaslow committee, and the local community, including tourism businesses) agreed that, to a greater extent, implementing Cittaslow in Goolwa was beneficial to the community in various ways in terms of local community involvement and empowerment.

As Cittaslow promotes continuous communication between community members to set and develop goals and strategies and identify the town's strengths, this study finds that this process of continuous dialogue has brought substantial and significant changes to the level of local community involvement and their subsequent empowerment in Goolwa. A stronger and more respectful collaboration between the stakeholders has been achieved, and the negative or sceptical attitudes once held by locals towards the equal importance of each stakeholder's involvement in tourism planning and development has become more positive. In this regard, both a local resident (R2) and one of the local business community members (R3) commented:

...Cittaslow is indeed encouraging all three important stakeholders to communicate and work together. They are the council (obviously headed by the Mayor), the community or local residents, and the local business community. It's important that we need all three parties [to] get involved in any tourism planning and development activities. We cannot have just the council because it's the community that makes it work. We cannot have the community do it because you need council to be inside to make sure the infrastructure is all right...it's important to have the local business community onboard, because they are the ones that are operating and supporting Cittaslow... (R2).

It was right after Cittaslow came in that the whole thing changed...people are getting more and more involved, and the council was listening to us (R3).

In particular, locals articulated that they were gradually realising the significant role of Cittaslow in enhancing the level of their participation and involvement in tourism activities. Indeed, the level of interaction and engagement between local residents and business communities was enhanced, as R7 commented that "Cittaslow is a symbol of Goolwa..., and 
local shops have been seen to be engaged and the community's ability to draw together for support is certainly evidenced." Compared to the town pre-Cittaslow, improved community cohesion, support and engagement were considered to be the main ingredients of social harmony and community cohesion as social empowerment that the local community perceived after the adoption of the Cittaslow. The local communities' agreement on the authentic identity of Goolwa, which is symbolised by the Cittaslow certification, was a result of collaboration in governing the natural and cultural resources of Goolwa. The power that was granted to conserve and utilise the natural and social assets of the town ultimately provided opportunities for locals to learn and appreciate what they shared in their living environments, and this learning process became a stimulus for local communities to engage with each other.

This study suggests that enhanced social empowerment effectively expands the individual's involvement in the political process. The considerable local community involvement in sustaining the region's tourism activities and resources was clearly recognised by all stakeholders as being the major difference between pre- and post-Cittaslow. Locals were even able to raise their collective voice and opinion in deciding on the allocation of social, cultural and environmental resources in the town to certain tourism activities and events, which demonstrates their enhanced political empowerment. The following quotation from R2 exemplifies this:

...when a new tourism related development is proposed, for example, if a company comes in Goolwa and suggests a business plan, now the locals can say 'no', if the business plan does not reflect what the community really wants (R2).

In contrast to institutional empowerment, the locals' political empowerment, along with their changed perceptions of their rights to control their own environment, led to more options being raised and adopted by local stakeholders and residents. Local residents' continuing involvement in new tourism project development and management has been achieved; more importantly, it has resulted in more local-oriented tourism experiences being offered to tourists. This is exemplified by two distinctive tourism development projects: the community garden project and the town-wide activity project of the food and wine sub-group. The former indeed encouraged many local residents to volunteer and take ownership of the town by decorating it and showing visitors where to go, what to see, and what to do. The latter led to stronger collaboration among the locals who participated in the food and wine sub-group of 
the Cittaslow committee. Both the local community (R6) and the local government (R1) agreed and supported this change, commenting:

The community garden is a classic example to show you the locals' involvement in Goolwa...it is operated entirely by the volunteers, I mean the locals, and they like to get involved. It is a great showcase to let the locals know about their local products (R1).

The garden became a good talking point for the locals and tourists who liked the idea of using local products... many local residents as volunteers took ownership of the town through the community garden project (R5).

...they [food and wine sub-group] meet regularly and talk about what's going on in their area, and their regular meetings are used as a means of communication among the locals, which is important ... Especially, the engagement with food and wine related tourism planning and development process was well supported by the locals (R1).

As such, the significant shift from little or passive participation prior to Cittaslow to far more proactive involvement in the whole process of tourism planning and development after Cittaslow, allowed the local community to firmly take ownership of the town. It also led to the generation of self-esteem and community pride among community members, as R3 suggests that "...in my opinion, the locals believe that it is a good thing to do, and they are proud to be part of Goolwa, and they want to put something back into the community." This finding implies that the local community in Goolwa has experienced an enhanced psychological empowerment from the Cittaslow (implementation process), as community pride and self-esteem in local cultural traditions and natural values are at the centre of psychological empowerment (Scheyvens, 1999).

This enhanced community empowerment is expressed through the improved selfperception by community members of their roles. All of the respondents agreed that the local community of Goolwa was more empowered after the adoption of Cittaslow status. In particular, their psychological empowerment was strongly exemplified by their perspectives on the value of locality, including the local business community. The following comments from respondents support this view: 
It is not all about money, but it is about our pride and ownership of our town, giving back a bit of time and energy to the town to sustain 'what Goolwa is' ... I have seen many locals expressing their pride about promoting the food and leisure aspects of Goolwa (R4).

...well, economic benefits or gains like employment opportunity would be an important aspect for the local's involvement, but I reckon, the self-esteem and pride of your own community would be much more important... you know... reason why we... (R3).

The above findings are interesting, because it is somewhat contrary to the findings of previous studies suggesting that empowerment is achieved when local communities benefit economically from tourism practices, and consequently their perception of their economic empowerment was the turning point in enhancing their involvement (Mendoza Ramos \& Prideaux, 2014). Although traditional meanings of economic empowerment were not visible in the form of financial distribution or increases in income from tourism involvement, this study suggests that the other three dimensions of empowerment were enhanced throughout the Cittaslow implementation process, and positively influenced the local community's involvement in tourism planning and development in Goolwa.

\section{Discussions}

Sustainable tourism through community empowerment is likely to be achieved through Cittaslow, as this concept utilises local skills and knowledge as fundamental resources for community development, and puts the community at the centre of decision-making process in relation to the improvement of quality of life across diverse social and environmental dimensions. Although Cittaslow is not an inherently tourism-focused movement (Hatipoglu, 2015), it has essential ingredients for the mechanism of sustainable tourism, especially community involvement and empowerment. Although few studies suggest that Cittaslow could be a great opportunity for tourism governance (Ekinci, 2014; Hatipoglu, 2015; Presenza et al., 2015), the findings of this study support the view that a small-scale Cittaslow (that is developed and managed by the local community) is well equipped with the essential elements of sustainable tourism planning and development. Thus, it suggests some recommendations for the potential of Cittaslow for facilitating local community involvement and thus enhancing their sense of community empowerment for a more effective implementation of sustainable tourism. 
In the case of Goolwa, a weak collaborative relationship between local residents, local businesses and the council was the main hindering factor of community involvement and empowerment. However, the adaptation and accreditation of Cittaslow was a turning point for both the government at various levels (e.g., local council, various levels of tourism organisations) and the local community. The existing literature supports the idea that the involvement of the local community in tourism planning and development is vital for creating an understanding between the government and the community about the appropriate and sustainable use of local resources (Jamal \& Stronza, 2009). This approach not only brings about effective local resource management but also creates a sense of community and positive attitudes among locals towards tourism activities. As evidenced in the case of Goolwa, enhanced political empowerment among local communities allowed the community and government bodies to communicate better, and this improved relationship also stimulated and enhanced the level of psychological and social empowerment.

The psychologically and socially empowered local community can have confidence in its ability to control its tourism resources more equitably and effectively in tourism planning, development and management (Scheyvens, 2002). This led to community capacity building and the reinforcement of the self-worth of community members. Jovicic (2014) emphasises the social and political values of sustainable tourism practices, which are still insufficient, in contrast to the greater consideration given to the economic and environmental sustainability of tourism. As an alternative to the practice of enhancing the socially sustainable aspect, community empowerment suits tourism development as it responds to the subjective needs of local communities. In this respect, the importance of the quality of life and the conservation of natural and social resources are highlighted (Jovicic, 2014). The members of Cittaslow are practicing these two vital issues through local community engagement, thereby enabling this more empowered community to also have a positive impact on tourism, which was evidenced in this study.

Local communities are seen to have competitive tourism advantages as they possess unique resources and a symbiotic relationship to the extent that they can contribute to their economic success, cultural survival and environmental preservation (Tao \& Wall, 2009). In this respect, local voices, values and knowledge should be proactively channelled into strategies for managing resources where participation is essential for sustainability, giving rise to a sense of ownership and empowerment (Stronza \& Durham, 2008). As the case of Goolwa demonstrates, enhanced political empowerment provides better opportunities for the local community to utilise their psychological and social empowerment to set up the ultimate 
goals of the community through the decision-making processes of tourism planning and development.

Meanwhile, this study has limited evidence to support the view that there is a significant change in economic empowerment, in contrast to the other three types of empowerment (i.e., social, psychological and political empowerment). This can be interpreted in the following three ways. First, the nature and ultimate goal of Cittaslow lies in the achievement of locality and high quality of life that are more relevant to social, psychological and perhaps political empowerment, whereas previous studies on local community empowerment in the context of community-based tourism mainly considered local participation as a means of financial distribution and poverty alleviation (e.g., Mendoza Ramos \& Prideaux, 2014; Sebele, 2010). Thus, the findings of this study could be seen as contradicting previous findings that have suggested that economic empowerment is always more visible than psychological and social empowerment. Second, this could be due to the short period of time in which Goolwa has been a Cittaslow town. Five years may not be long enough to perceive any visible financial and economic changes. As the Cittaslow philosophy highlights quality of life and a slow pace of life, the adoption of Cittaslow status, and the changes this entails paralleled with the slow tourism movement, do not happen quickly. Third, this study reported positive changes in community involvement and empowerment in decision-making in the context of a developed country that is Australia. In the meantime, it has been commonly noted that local residents' and stakeholders' involvement in decisionmaking processes in tourism projects is often especially challenged in developing countries (e.g., Malaysia, Mongolia, Bolivia, etc.), because decisions are often made in political institutions or in collaboration with external parties, and not all stakeholders can speak openly (Marzuki, Hay, \& James, 2012; Moscardo, 2008; Nault \& Stapleton, 2011).

\section{Conclusions and Implications for Future Research}

With the above discussions, a longitudinal study in this area would be welcome to examine the town's economic empowerment. Future research could investigate how economic empowerment is related to the other dimensions of community empowerment in the context of both Cittaslow and non-Cittaslow locations as potential tourism destinations. Also, future studies examining the structure of community empowerment and the antecedents and consequences of it would be welcome, as this is still unclear. Lastly, the extent to which Cittaslow's contribution to the enhancement of local communities' empowerment in tourism development needs to be examined in the context of both developed and developing countries 
as well as regions in the world. As suggested by Ekinci (2014), a comparative study would be much beneficial. It will be worthwhile investigating whether the implementation of Cittaslow is useful for tourism development in developing regions considering the nature and basic philosophy pursued.

A methodological limitation remains in terms of the sample size. This limitation lies in the characteristics of the research design, which aimed to conduct a series of in-depth interviews with local residents who had lived in Goolwa long enough to comment on their perceptions of the impacts of Cittaslow on the community's involvement and empowerment by comparing the town pre- and post-Cittaslow accreditation. It is, however, better to have a larger sample size for empirical research, and thus future work could build upon the findings of the present study using other methods and/or a larger sample size.

To conclude, the process of Cittaslow implementation can be a driving force of sustainable tourism destination development, and the practicality of sustainable tourism development associated with local community involvement and empowerment, is more effectively achieved. Not only does the continuing engagement and conversation among the community's members and the public sector enhance the level of local community involvement, but it also influences the attitudes and perceptions of the locals towards the importance of their involvement in the decision-making process of tourism development. Although tourism is just one component of the wider Cittaslow concept, the process of strengthening local identity and promoting and engaging with local resources developed the components and attractions of substantial tourism; for example, heritage, a high quality environment, and food and wine, as the case of Goolwa demonstrated. Respecting local culture and authentic local components were indeed a target area of quality tourism experiences, and are often referred to in the slow tourism literature (Heitmann et al., 2011). The local community-led products and services practiced as part of the Cittaslow project are more likely to appeal to tourists; as such, Cittaslow per se is viewed as suitable for smallscale, local-oriented tourism destinations where sustainable tourism is effectively practiced with active community involvement.

Indeed, the local community in Goolwa strongly supported the benefits of Cittaslow, because they were able to take ownership of the town, have more control over their living environment, and develop their town's strengths. This active engagement with the development of local events, the community garden project and the promotion of the locality, created saleable tourism activities in Goolwa. Tourism activities were directed by local residents, and thus tourism benefited local communities and provided visitors with better 
opportunities to get to know Goolwa, as they were introduced to and guided around the town by local people. Local communities should collaborate and pay attention to managing the established tourism projects in sustaining Cittaslow certification through periodic reviews. As such, sustainable tourism is highly likely to be maintained in Goolwa now that it is coupled with Cittaslow practices. 


\section{References}

Adams, R. (1990). Self-help, social work and empowerment. London: Macmillan Education.

Akama, J. (1996). Western environmental values and nature-based tourism in Kenya. Tourism Management, 17(8), 567-574.

Boley, B. B., \& McGehee, N. G. (2014). Measuring empowerment: Developing and validating the resident empowerment through tourism scale. Tourism Management, 45, 85-94.

Boley, B. B., Maruyama, N., \& Woosnam, K. M. (2015). Measuring empowerment in an eastern context: Findings from Japan. Tourism Management, 50, 112-122.

Bramwell, B. (2010). Participative planning and governance for sustainable tourism. Tourism Recreation Research, 35(3), 239-249.

Bramwell, B., \& Sharman, A. (2000). Approaches to sustainable tourism planning and community participation: The case of the Hope Valley. In G. Richard, \& D. Hall (Eds.), Tourism and sustainable community development (pp. 17-35). London: Routledge

Briassoulis, H. (2002). Sustainable tourism and the question of the commons. Annals of Tourism Research, 29(4), 1065-1085.

Bryman, A. (2004). Social Research Methods (2 ${ }^{\text {nd }}$ ed.). Oxford: Oxford University.

Byrd, E. T., Bosley, H. E., \& Dronberger, M. G. (2009). Comparisons of stakeholder perceptions of tourism impacts in rural eastern North Carolina. Tourism Management, 30(5), 693-703.

Cole, S. (2006). Information and empowerment: The keys to achieving sustainable tourism. Journal of Sustainable Tourism, 14(6), 629-644.

Conway, D., \& Timms, B. (2010). Re-branding alternative tourism in the Caribbean: The case for 'slow tourism'. Tourism \& Hospitality Research, 10(4), 329-344.

Conway, D., \& Timms, B. (2012). Are slow travel and slow tourism misfits, compadres or different genres? Tourism Recreation Research, 37(1), 71-76.

Dickinson, J. E., \& Lumsdon, L. (2010). Slow travel and tourism. New York: Earthscan.

Dickinson, J. E., Lumson, L. M., \& Robbins, D. (2011). Slow travel: Issues for tourism and climate change. Journal of Sustainable Tourism, 19(3), 281-300.

Dodds, R. (2012). Questioning slow as sustainable. Tourism Recreation Research, 37(1), 8183.

Ekinci, M. B. (2014). The Cittaslow philosophy in the context of sustainable tourism development; the case of Turkey. Tourism Management, 41, 178-189. 
Farrelly, T. A. (2011). Indigenous and democratic decision-making: Issues from communitybased ecotourism in the Boumā National Heritage Park, Fiji. Journal of Sustainable Tourism, 19(7), 817-835.

Friedmann, J. (1992). Empowerment: The politics of alternative development. Malden, MA: Blackwell Publishers.

Gang, C. (2010). Sustainable development of eco-cultural tourism in remote regions: Lessons learned from Southwest China. International Journal of Business Anthropology, 2(1), $123-135$.

Goodwin, H. (2007). Indigenous tourism and poverty reduction. In R. Butler \& T. Hinch (Eds.), Tourism and indigenous peoples: Issues and implications (pp. 84-94). Oxford, UK: Elsevier.

Hatipoglu, B. (2015). "Cittaslow”: Quality of life and visitor experiences. Tourism Planning \& Development, 12(1), 20-36.

Heitmann, S., Robinson, P., \& Povey, G. (2011). Slow food, slow cities and slow tourism. In P. Robinson, S. Heitmann, \& P. U. C. Dieke (Eds.), Research themes for tourism (pp. 114-127). Oxford: CABI.

Hoeschele, W. (2010). Measuring abundance: The case of Cittaslow's attempts to support better quality of life. International Journal of Green Economics, 4(1), 63-81.

Jackson, G., \& Morpeth, N. (1999). Local agenda 21 and community participation in tourism policy and planning: Future or fallacy. Journal of Sustainable Tourism, 2(1), 1-38.

Jamal, T., \& Stronza, A. (2009). Collaboration theory and tourism practice in protected areas: Stakeholders, structuring and sustainability. Journal of Sustainable Tourism, 17(2), $169-189$.

Jovicic, D. Z. (2014). Key issues in the implementation of sustainable tourism. Current Issues in Tourism, 17(4), 297-302.

King, B., \& Pearlman, M. (2009). Planning for tourism at local and regional levels: Principles, practices and possibilities. In T. Jamal \& M. Robinson (Eds.), The Sage Handbook of Tourism Studies (pp. 416-431). London, UK: Sage.

Knox, P. L. (2005). Creating ordinary places: Slow cities in a fast world. Journal of Urban Design, 10(1), 1-11.

Lapeyre, R. (2010). Community-based tourism as a sustainable solution to maximise impacts locally? The Tsiseb Conservancy case, Namibia. Development Southern Africa, 27(5), $757-772$. 
Lowry, L., \& Back, R. (2015). Slow food, slow tourism, and sustainable tourism: A conceptual model. In H. G. Parsa (Ed.), Sustainability, social responsibility and innovations in tourism and hospitality (pp. 71-89). Oakville, ON: Apple Academic Press, Inc.

Lowry, L., \& Lee, M. (2011). CittaSlow, slow cities, slow food: Searching for a model for the development of slow tourism. Travel \& Tourism Research Association, 42nd Annual Conference Proceedings: Seeing the Forest and the Trees - Big Picture Research in a Detail- Driven World, June 19-21, 2011, London, Ontario, Canada, 1-13. Retrieved from http://works.bepress.com/lowry_linda/3/

Marzuki, A., Hay, I., \& James, J. (2012). Public participation shortcomings in tourism planning: The case of the Langkawi Island, Malaysia. Journal of Sustainable Tourism, $20(4), 585-602$.

Mayer, H., \& Knox, P. L. (2006). Slow cities: Sustainable places in a fast world. Journal of Urban Affairs, 28(4), 321-334.

Mayer, H., \& Knox, P. L. (2009). Pace of life and quality of life: The slow city charter. In M. Sirgy, D. R. Rahtz, \& T. J. Yi (Eds.), Community quality-of-life indicators: Best cases III (pp. 21-40). Netherlands: Springer.

Mendoza Ramos, A., \& Prideaux, B. (2014). Indigenous ecotourism in the Mayan rainforest of Palenque: Empowerment issues in sustainable development. Journal of Sustainable Tourism, 22(3), 461-479.

Miretpastor, L., Peiró-Signes, Á., Segarra-Oña, M., \& Mondéjar-Jiménez, J. (2015). The slow tourism: An indirect way to protect the environment. In H. G. Parsa (Ed.), Sustainability, social responsibility and innovations in tourism and hospitality (pp. 317-339). Oakville, ON: Apple Academic Press, Inc.

Moscardo, G. (2008). Sustainable tourism innovation: Challenging basic assumptions. Tourism and Hospitality Research, 8(1), 4-13.

Moyle, B., Croy, G., \& Weiler, B. (2010). Community perceptions of tourism: Bruny and Magnetic islands, Australia. Asia Pacific Journal of Tourism Research, 15(3), 353366.

Nault, S., \& Stapleton, P. (2011). The community participation process in ecotourism development: A case study of the community of Sogoog, Bayan-Ulgii, Mongolia. Journal of Sustainable Tourism, 19(6), 695-712. 
Nilsson, J. H., Svärd, A.-C., Widarsson, A., \& Wirell, T. (2011). “Cittáslow” ecogastronomic heritage as a tool for destination development. Current Issues in Tourism, 14(4), 373-386.

Nyaupane, G. P., Morais, D. B., \& Dowler, L. (2006). The role of community involvement and number/type of visitors on tourism impacts: A controlled comparison of Annapurna, Nepal and Northwest Yunnan, China. Tourism Management, 27(6), $1373-1385$.

Okazaki, E. (2008). A community-based tourism model: Its conception and use. Journal of Sustainable Tourism, 16(5), 511-529.

Parkins, W., \& Craig, G. (2006). Slow living. Oxford: Berg.

Pink, S. (2007). Sensing Cittàslow: Slow living and the constitution of the sensory city. The Senses and Society, 2(1), 59-77.

Pink, S. (2008). Sense and sustainability: The case of the Slow City movement. Local Environment, 13(2), 95-106.

Presenza, A., Abbate, T., \& Micera, R. (2015). The Cittaslow Movement: Opportunities and Challenges for the Governance of Tourism Destinations. Tourism Planning \& Development, (iFirst). http://doi.org/10.1080/21568316.2015.1037929

Radstrom, S. (2014). A place-sustaining framework for local urban identity: An introduction and history of Cittaslow. Italian Journal of Planning Practice, 1(1), 90-113.

Rappaport, J. (1987). Terms of empowerment/exemplars of prevention: Toward a theory for community psychology. American Journal of Community Psychology, 15(2), 121148.

Richard, G., \& Hall, D. (2000). The community: A sustainable concept in tourism development? In G. Richard, \& D. Hall (Eds.), Tourism and sustainable community development (pp. 1-13). London: Routledge

Ritchie, J., Spencer, L., \& O'Connor, W. (2003). Carrying out qualitative analysis. In J. Ritchie, \& J. Lewis (Eds.), Qualitative research practice: A guide for social science students and researchers (pp. 219-262). London: Sage.

Ritzer, G. (2011). The McDonaldization of Society 6. Thousand Oaks, California: Pine Forge Press.

Saarinen, J. (2010). Local tourism awareness: Community views in Katutura and King Nehale Conservancy, Namibia. Development Southern Africa, 27(5), 713-724. 
Scherl, L. M., \& Edwards, S. (2007). Tourism, indigenous and local communities and protected areas in developing nations. In R. Bushell \& P. F. J. Eagles (Eds.), Tourism and protected areas: Benefits beyond boundaries (pp. 71-89). Wallingford: CABI.

Scheyvens, R. (1999). Ecotourism and the empowerment of local communities. Tourism Management, 20(2), 245-249.

Scheyvens, R. (2002). Tourism for development: Empowering communities. New Jersey: Pearson Education.

Sebele, L. S. (2010). Community-based tourism ventures, benefits and challenges: Khama rhino sanctuary trust, central district, Botswana. Tourism Management, 31(1), 136146.

Sharpley, R. (2000). Tourism and sustainable development: Exploring the theoretical divide. Journal of Sustainable Tourism, 8(1), 1-19.

Simpson, M. C. (2008). Community benefit tourism initiatives-A conceptual oxymoron? Tourism Management, 29(1), 1-18.

Simpson, F., \& Roberts, L. (2000). Help or hindrance? Sustainable approaches to tourism consultancy in Central and Eastern Europe. Journal of Sustainable Tourism, 8(6), 491-509.

Stone, L. S., \& Stone, T. M. (2011). Community-based tourism enterprises: Challenges and prospects for community participation; Khama Rhino Sanctuary Trust, Botswana. Journal of Sustainable Tourism, 19(1), 97-114.

Stronza, A., \& Durham, W. H. (2008). Ecotourism and conservation in the Americas. Wallingford: CABI.

Strzelecka, M., \& Wicks, B. E. (2015). Community participation and empowerment in rural post-communist societies: Lessons from the leader approach in Pomerania, Poland. Tourism Planning \& Development, (iFirst). http://doi.org/10.1080/21568316.2015.1013564

Tao, T. C. H., \& Wall, G. (2009). Tourism as a sustainable livelihood strategy. Tourism Management, 30(1), 90-98.

Telfer, D. J. (2003). Development issues in destination communities. In S. Singh, D. J. Timothy, \& R. K. Dowling (Eds.), Tourism in destination communities (pp. 155-180). UK: CABI.

Timothy, D. J. (2007). Empowerment and stakeholder participation in tourism destination communities. In A. Church \& T. Coles (Eds.), Tourism, power and space (pp. 199216). London, UK: Routledge. 
Tosun, C. (2006). Expected nature of community participation in tourism development. Tourism Management, 27(3), 493-504.

Tosun, C., \& Timothy, D. J. (2003). Arguments for community participation in the tourism development process. Journal of Tourism Studies, 14(2), 2-15.

Weng, S., \& Peng, H. (2014). Tourism development, rights consciousness and the empowerment of Chinese historical village communities. Tourism Geographies: An International Journal of Tourism Space, Place and Environment, 16(5), 772-784.

Yüksel, F., Bramwell, B., \& Yüksel, A. (2005). Centralized and decentralized tourism governance in Turkey. Annals of Tourism Research, 32(4), 859-886. 